\title{
Eddies and Entanglements: Africa and the Global Mnemoscape
}

\author{
Lauren van Der Rede and Aidan Erasmus
}

Fig. 5.1 The Ethiopian

Red Terror Martyrs

Memorial Museum in

Addis Ababa, showing a

replica of the blood-

filled bottle used by

Mengistu to signal the

start of the Red Terror, the faces of 755

individuals on the Derg

"wanted list" and (1977)

(reflected in the vitrine)

the faces of the

disappeared who are still

missing (Lauren van

der Rede)

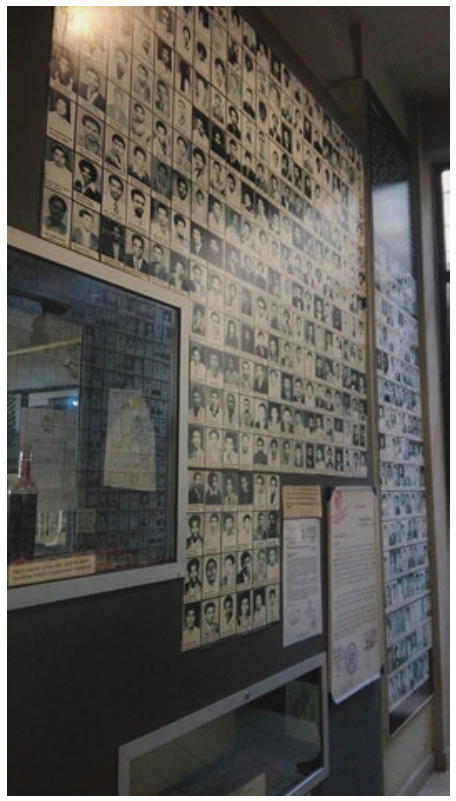

(C) The Author(s) 2021

J.-H. Lim, E. Rosenhaft (eds.), Mnemonic Solidarity, Entangled

Memories in the Global South,

https://doi.org/10.1007/978-3-030-57669-1_5 
Abstract Van Der Rede and Erasmus provocatively characterize Africa as a "disobedient object" of memory studies, posing a series of radical challenges to the terms and methods of the field. In empirical terms, they point out how two specific cases, the Red Terror in Ethiopia and States of Emergency during Apartheid in South Africa, inflect our Europe-centered models of trauma and memory. Beyond this, positing Africa "not as a cartographic and geological location but as a concept and methodology," van Der Rede and Erasmus challenge the liberal universalism implicit in the problematics of memory studies (and indeed in the notion of mnemonic solidarity) with an insistence on hearing/listening rather than speaking that draws on postcolonial theory and the new methods of sound studies.

Keywords Africa and the global mnemoscape - Ethiopian Red Terror - South Africa's states of emergency • Genocide - Ethiopia - South African apartheid

\section{Resisting the Knot: Memories and Their Allegiances}

The grains of Ethiopia and South Africa's histories grate differently, though the irony with which they are held within the context of the study of the past is uncanny-be it memory or historical studies. The first of these spaces was never formally colonized, was itself an empire and remains synonymous with a politics of resistance, but is also a site of atrocities which the international community calls terror and local law recognizes as genocide. The second, in the infancy of its democracy, remains swaddled by the legacy of colonialism. It is a site of the extreme violence that accompanied institutionalized and legislated racism which

L. van Der Rede $(\bowtie)$

Department of English, Stellenbosch University, Cape Town, South Africa e-mail: lvdr@sun.ac.za

A. Erasmus

Department of History, University of the Western Cape, Bellville, South Africa e-mail: aerasmus@uwc.ac.za 
saw multiple states of emergency and yet is revered for its constitutional progressiveness. What drops out between the Ethiopian Red Terror and apartheid South Africa's states of emergency is precisely that around which they are congealed, become knotted together and in place, as "then and there" from the "here and now." Said differently, it is the refusal to think seriously not only of the violence of colonialism but of colonialism as violence that produces a knot from which African examples of genocide and war cannot come undone. Consequently, it remains that judgments pertaining to the veracity and value of violence lived and lives lost remain skewed. What the spaces of Ethiopia and South Africa offer us is a moment in and through which to respond to the call for a mnemonic solidarity: a call for the democratization of the global mnemoscape. This call, which itself carries a charge that requires attention, asks not so much what the form or content of a global mnemoscape might look like but rather what its movement looks like, the churning of its subjects and the eddying of its temporalities. To read, hear, and respond to mnemonic solidarity as a call-in some sense, a summonshas at the outset a grounding assumption: that one has the potential and capacity to both hear and listen of and to the persons whose subjecthood is textured by the discursive punctures of the global mnemoscape. We understand these punctures to be those ruptures that perforate the desire for a discourse of memory that might encompass the world through a different kind of solidarity of the present that can express the past without fetishizing it. These punctures, we argue, must be attended to if we are to embark on the task of the democratization of the global mnemoscape, let alone constitute a solidarity around its many parts.

Thus, in these terms, a call for mnemonic solidarity should be read as marking both a desire for and a movement toward dismantling the territorializing effect of mnemonic discourses on colonialism, war, and genocide. The desire aforementioned is a response to the multitemporal and multispatial sear of colonialism, war and genocide as violence as politics, still unfolding histories, and divergent memories. Moreover, this desire is embedded in the call to think through these expressions of violence in a mode that democratizes, without flattening contextual specificity, the global mnemoscape. To set to work and realize a global mnemoscape would mean abiding by this beckoning, and allowing an entanglement of memory that would democratize rather than universalize mnemonic discourses. If we are to address certain disciplinary and methodological inheritances, such an entanglement is critical, and 
particularly useful insofar as it is a system of value that does not conform to an ordering of human suffering that must produce hierarchies as its structuring dynamic.

What follows will be an attempt to register how one might responsibly answer such a beckoning, from the vantage point of a non-geographically demarcated Africa, and its stakes in the wake of the formulation and deployment of the global mnemoscape and its own desire for solidarity. We will explore this position through an analysis of what we deem two mnemonically disobedient devices: Ethiopia's Red Terror as genocide, and the ambiguity of time and war encapsulated in apartheid South Africa's states of emergency. South Africa and Ethiopia are mnemonically disobedient objects insofar as they bear the marks of the knottiness of their relation to the past in the present. They disobey injunctions to be rendered as constellations of violent events, refuse historicism as a logic of the past, and evade a register that would reduce its subjects and objects to violence laid bare. As disobedient signifiers that operate as subjects within the mnemoscape, they demand coevalness, they resist, unsettle, and undermine the disciplinary functions of the discourses of genocide, war, and colonialism. For better or worse, they bear the marks of a difference that troubles - eddies - the regime of historicity that would read colonialism as an event.

\section{Ethiopia: Eddying Genocide And Terror}

Ethiopia is one space through which to respond to a call of mnemonic solidarity. Having ratified the Convention on the Prevention and Punishment of the Crime of Genocide (1948) in the year of its enactment, the country later also translated the definition of genocide into its Penal Code (1957), expanding thereon to provide protection for not only racial, ethnic, national, and religious groups, but also political groups. It is as a result of this elaboration that after the dismantlement of the Derg regime in 1991, the Special Prosecutor for the local courts was able to charge persons responsible for the Ethiopian Red Terror (officially c. 1976-78) with the crime of genocide. By contrast, in the chambers of the International Criminal Court (ICC), perpetrators of the Red Terror could only be charged with War Crimes, as a recent case has shown. ${ }^{1}$

1 "Ethiopia: 'Red Terror' war crimes trial begins at The Hague," BBC, October 30, 2017, https://www.bbc.com/news/world-africa-41802232. 
In the years prior to, but also through and beyond, the Revolution of 1974, Ethiopia was a land of contradiction, stratified above all else by class divisions. The capital was home to well over a million Ethiopians, the vast majority of whom constituted the working middle and lower classes, who depended in many ways on the peasant class of Ethiopia for the agricultural supplies of everyday life. However, as a result of the famine(s) which ravaged rural Ethiopia in the early 1970s this chain of supply and demand was broken, and the plight of the rural in many ways thus became the plight of the urban. It was this permeation of urban and rural/upper and lower classes, and the cruel irony of the "Hidden Famine" of 1973 coinciding with the extravagance of Emperor Haile Selassie that ignited the Marxist-Socialist Revolution, led by parties of student movements and the intelligentsia, and consolidated by the military.

Following the deposition and later the murder of Emperor Haile Selassie in 1974 the Derg, a nominally Marxist faction which had splintered away from the rest of the military, took power and ruled Ethiopia until 1991, not through democratic redress but through fear. The Red Terror is generally associated with the years 1977-78, but it is important to note that the military junta's violence, indeed its brutality, did not spontaneously begin in 1977, or abruptly end in 1978; nor does it necessarily operate along these lines as memory. Rather the violence which reached a peak during those years, and many thereafter, had been creeping, slow to become visible but encroaching evermore on the peoples of Ethiopia. Some Ethiopians may have/still remember the brutality of the war with Italy, and its brief occupation in the 1930s, as well as the devastating and drawn-out conflict with Eritrea over its independence. Thus, the acts committed by the Derg as well as those under its command and civilian allies were made practice well before the revolution. Rather, through the terror the Derg returned the brutality perpetrated against Ethiopians in the name of Italian colonization, and against Eritreans who struggled for independence from Ethiopia since 1961, on Ethiopia itself. In this way the Derg did, much as Aimé Césaire argues the Nazis did to Europe, return the barbarity of colonialism and empire to Ethiopia. ${ }^{2}$

The Derg began a campaign of repression banning any opposition parties and inaugurating military rule, thus disavowing the desire for democratization. Moreover, it subjected its opponents to acts of cruelty which

\footnotetext{
${ }^{2}$ Aimé Césaire, Discourse on Colonialism, trans. J. Pinkham (New York: Monthly Review Press, 2000).
} 
are considered gross human rights violations and crimes against humanity, including: killing, torture, abduction, and disappearance. However, the Derg also banned any "anti-revolutionary" literature, which is to say texts which attempted to activate resistance against the military regime, including "ABYOT," "Struggle," 3 and others, going so far as to destroy the machinery of print. These acts of violence are not unique to the Derg and are familiar to presumably most persons in any part of the world today as expressions of particular kinds of logic. For example, killing, torture, disappearance are included as constitutive acts in the definition of genocide provided in international law by the United Nations (UN) Convention on the Prevention and Punishment of the Crime of Genocide $(1948)^{4}$ and the Rome Statute of the International Criminal Court (ICC) (1998).

Rather, as mentioned previously, what sets genocide aside from other forms of extreme and systemic violence is its mens rea: “... intent to destroy..." Terror's mens rea, however, may be understood as the desire to coerce another group into subjugation by holding them hostage through fear. As Igor Primoratz explains, the logic of terror is such that it works to intimidate "innocent" people "into a course of action that they would otherwise not take" through "the deliberate use of violence, or the threat of its use." In this sense, terror has two targets. The first is the direct target of an attack, subjected to those acts which constitute the manifest, blatant violence of terror. This target is the person who is presumed to be an immediate threat to the regime and is subjected to forced disappearance and kidnapping, torture, and killing, and so on. Through rumor and the displaying of the deceased in the streets of the capital and its surrounds the Derg made that direct violence spectacular at the same time as it was clandestine. And when bodies were dumped in the city streets, this spectacular violence also became a part of the quotidian, as communities were directly policed through the clustering of every approximately five homes in a neighborhood (kebeles) administered by civil servants of the regime (kebele officers).

On the one hand, killing, abduction, disappearance, and torture served to illuminate the person identified as a threat to the regime. What is

\footnotetext{
${ }^{3} \mathrm{ABYOT}$ was an independent, resistance pamphlet printed in both Amharic and English circulating as a mode of critiquing the Derg; while its English counterpart "Struggle" was a pamphlet published by the University Students' Union of Addis Ababa.

${ }^{4}$ Hereafter simply referred to as the Genocide Convention.

${ }^{5}$ Igor Primoratz, "What is Terrorism?" in Terrorism: The Philosophical Issues, ed. Igor Primoratz (New York: Palgrave Macmillan, 2004), 15-27.
} 
significant to note here is that the identification of a person as an enemy of the Derg - and as such by extension the state-was not self-identification; the individual him/her/themselves did not necessarily identify as oppositional to the state, unless he/she/they were in fact a member of politically oppositional groups such as the Ethiopian People's Revolutionary Party (EPRP) and Meison. Rather, he/she/they needed only to be named, suspected and as such marked as an opponent to the regime in order for said person to be considered "anti-revolutionary," "terrorist," "anti-Ethiopia," and therefore necessary to eliminate. The condition for this elimination of an opponent, this first constellation of techniques of terror, is premised on conspiracy and suspicion, whereby the accused is presumed guilty until proven innocent.

The true brutality of the Derg's rule is that it rendered spectacular violence quotidian, and in so doing assaulted its second, indirect target-the civilians who survive to bear witness, and whose witnessing in turn produced the fear through which the Derg held hostage the population and simultaneously subjugated the people. This is the primary object of terror: The direct victim who is subjected to killing, torture, and so on is conscripted as a mechanism through which to activate the fear that will take hostage and subjugate those who remain. It is the indirect victim, left to live with the constant threat of being made a direct victim, who is of primary importance. In this sense the violence directly enacted on a single person is displaced onto a group of people. The dumping of victims' bodies in the streets of Addis Ababa is one of the techniques through which this is achieved, registering as public display the culmination of the cruelty of the Derg. It is a warning that inspires foreboding that is affirmed when messages are left on the body that read "I am an enemy of the people. Mother, don't weep for me, I deserved to die." In some instances, these notes explaining murder as deserved punishment for (being suspected of) opposing the Derg are placed on the person before they are in fact executed-as an artwork in the Red Terror Martyrs Memorial Museum (RTMMM) in Addis Ababa suggests. In this artwork a row of people is depicted against a red, unevenly shaded backdrop; the first from the left appears to be a priest, then a woman, four men, a woman in front of whom stands a boy child, a woman in hijab, and finally another man. Of this scale of individuals, all of whom have their hands out of view (thus

\footnotetext{
${ }^{6}$ Maaza Mengiste, Beneath the Lion's Gaze: A Novel (New York: WW Norton \& Company, $2010), 240$.
} 
presumably bound), and all are met with shadowed silhouettes shaped quite like a Kalashnikov.

What is at stake in the difference produced by the labeling of some of the soon-to-be-shot is that not all of the victims of the Derg and particularly the Red Terror were necessarily themselves members of political opposition or even identified as such. Some victims were subjected to this kind of violence purely on the grounds of being associated with someone who was presumed a threat to the regime. What this gestures toward is a feature of the figure of the terrorist which distinguishes it from the assassin or the revolutionary, for example. As Primoratz explains, this feature is the inability to distinguish between guilty and innocent, and in this context it is this inability that contributes along with the spectacular violence like that of the Derg, to the paranoia through which entire populations are held hostage through terror.

Techniques of terror are textured differently and include various mechanisms - activating gestures - that render it visible and audible to the primary target and in so doing produce witnesses and testimony, so as to activate fear. The public display of mutilated bodies, the refusal to return or reveal the location of the disappeared (living or not), and the letting live and release of victims of torture made knowable the extent of cruelty to which the Derg was willing to go. Terror through its mechanisms and techniques deploys fear's interpellative potential to subjugate. ${ }^{7}$ Terror acts by rendering the spectacular quotidian. But the everydayness of the excessive violence in response to the anxiety of a regime is not mundane; despite its routineness and its imposed cohabitation the spectacular violence of the Derg's project of terror did not lose its charge. Rather it continued and continues in some ways to sear the lived experience of Ethiopians, as is clear from the growing exhibition in the Red Terror Martyrs Memorial Museum, in Addis Ababa. ${ }^{8}$

\footnotetext{
${ }^{7}$ On interpellation, see L. Althusser, "Ideology and Ideological State Apparatuses (Notes towards an Investigation)," in Lenin and Philosophy and Other Essays, trans. B. Brewster (New York: Monthly Review Press, 2001), 11-44.

${ }^{8}$ In addition to the sources listed in footnote 5, see Edward Kissi, "'Remembering Ethiopia's Red Terror: History of a Private Effort to Preserve a Public Memory," in Documenting the Red Terror: Bearing Witness to Ethiopia's Lost Generation, ed. Hirut AbebeJirut (Ottawa, Ethiopian Red Terror Documentation and Research Centre (ERTDRC), 2012), 9-24; Lauren van Der Rede, "Disappeared to Ethiopia's Bermuda: Tales by a Puppet," Kronos vol. 44 no. 1 (2018): 196-210, https://doi.org/10.17159/2309-9585/ 2018/v44a12; Deirdre McQuillan, "Ethiopia Still Haunted by Memory of Derg Genocidal
} 
In the wake of the dismantling of the military regime in 1991, the Ethiopian state was tasked with addressing the atrocities committed as part of the terror sowed by the Derg, in the absence of any legal protections against the offense of "terrorism" or "terror." It is important to note that terrorism is a crime against international customary law, like genocide, but unlike genocide does not have a central guiding and accepted definition from which other forms of legislation, including local legislation, can take its cue. ${ }^{9}$ Rather, terror is defined largely according to a state's own definitions (and needs), as South Africa did in 1967 and Ethiopia would do only in 2009. Accordingly, the members of the Derg who were tried during the Red Terror Trials were charged with the crime of and offenses relating to genocide, and not in fact terror. The prosecution relied on the definition of genocide provided by its Penal Code of 1957, which is an adaptation of the definition enshrined in the Genocide Convention (and later the Rome Statute). What enabled this is a distinguishing feature of the Ethiopian definition of genocide laid out in the Penal Code of 1957, namely that in addition to racial, ethnic, religious, or national groups, political groups are protected as well.

It was on these grounds that democratic Ethiopia took a retributive approach to justice and charged 27 members of the Derg, including "chairman" Mengistu Haile Mariam, with Crimes Against Humanity and Genocide, and not "Terrorism." This is significant because it gestures toward a misfire in the praxis of naming violence and attending to that violence. The irony of naming the atrocities committed in Ethiopia by the Derg terror but the charging perpetrators with genocide points a veiling of the eponymous quality of Ethiopia's Red Terror, which was named after the Red Terror perpetrated by the Bolsheviks in Russia approximately 60 years before. What is lost if we do not mark this irony is a turning to

Regime," The Irish Times, May 6, 2011, https://www.irishtimes.com/news/ethiopia-stillhaunted-by-memory-of-derg-genocidal-regime-1.563626.

${ }^{9}$ Terrorism, as a legal concept, has proved slippery in so far as defining it as a crime of international law is concerned. However, since the 1960's there have been numerous sectoral counter-terrorism interventions. These include the Convention on Offenses and Certain Other Acts Committed On Board Aircraft (1963), the Convention on the Physical Protection of Nuclear Material (1979), the International Convention for the Suppression of Terrorist Bombings (1997), and the International Convention for the Suppression of Acts of Nuclear Terrorism (2005). See Ben Saul, "The Legal Response of the League of Nations to Terrorism," Journal of International Criminal Justice 4 (2006): 78-102; and Ben Saul, "Speaking of Terror: Criminalizing Incitement to Violence," The University of New South Wales Law Journal (UNSW Law Journal) 28 no. 3 (2005): 868-86. 
Europe that is colored not by a desire to become a Westernized subject, but rather a desire to learn barbarity. The definition of genocide provided in the Ethiopian Penal Code of 1957 is more elaborate than the definition provided in the Genocide Convention and the Rome Statute. Under Article 281 of Title II of the Ethiopian Penal Code of 1957, Offenses against the Law of Nations, Chapter 1 (Fundamental Offenses) genocide is defined as follows:

Genocide; Crimes against Humanity.

Whosoever, with intent to destroy, in whole or in part, a national, ethnic, racial, religious, or political group, organizes, orders, or engages in, be it in time of war or in time of peace:

(a) Killings, bodily harm or serious injury to the physical or mental health of members of the group, in any way whatsoever; or

(b) Measures to prevent the propagation or continued survival of its members or their progeny; or

(c) The compulsory movement or dispersion of peoples or children, or their placing under living conditions calculated to result in their death or disappearance, is punishable with rigorous imprisonment from five years to life, or, in cases of exceptional gravity, with death.

The disjuncture between this articulation of the crime of genocide and that of the Genocide Convention begins with its framing, or title, in which genocide and crimes against humanity are named alongside each other, as equally offensive and as such, of equal importance. However, the legislation above sands away the grains of difference between genocide and crimes against humanity. Although the constitutive acts are shared by the two offenses, the mental element of these crimes which produces them as different is negated. According to the Rome Statute genocide is committed with "intent to destroy, in whole or in part, a racial, ethnical, nation or religious group, as such" (Article 6); while crimes against humanity are violent acts committed "as part of a widespread or systematic attack directed against any civilian population, with knowledge of the attack" (Article 7). There are a number of reasons why the way in which the Ethiopian legislation expresses the mens rea shared between genocide and crimes against humanity is significant.

First, it marks the perpetrator of these crimes as a subject: "whosoever," while neither the Genocide Convention nor the Rome Statute marks an activating agent in its definition of genocide, and in the case of the Rome 
Statute, crimes against humanity. This invocation of the subject-indeed of the human-is significant because it marks that there are people on both sides of atrocity. Second, this guilty subject is not only a person who commits one of these acts him/her/theirself but also someone who orders or engages in it, thus preemptively undoing the defense that many Nazis used at Nuremberg during the Military Tribunals (1945-46). In doing so-in opening what it means to actively participate in atrocity-it also explodes the question of complicity. Thus, the third point of significance: that the Ethiopian Penal Code of 1957 was a response to the Holocaust, in that it translated genocide and crimes against humanity (an offense adopted in the Charter of the International Military Tribunal, or the Nuremberg Charter) into legislation as lessons from Nuremberg. Fourth, the legislation marks that both genocide and crimes against humanity can occur during times of war (between states) and peace. ${ }^{10}$ This is important because it marks that interstate war is not violence's condition, but rather that there is the potential during times of peace for a different kind of war, in which the state reads as its enemy and takes as its target not another state and its agents, but its own people. This kind of war is what Raphael Lemkin in 1948 called genocide-what Ethiopians in the 1970s would call terror-and what South Africa for most of the second half of the twentieth century knew as apartheid.

\section{Listening And Hearing: Of Modes}

To achieve what a call for mnemonic solidarity whispers as its desired object requires reckoning with an Africa that sits beyond its geographic designation as place. This means that what is necessary is to register Africa as a concept for thinking the global mnemoscape as a site that is not situated, and what may be useful in this is a leaning toward modes of aurality-hearing and listening - as interpretive signposts to help us map the texture of the past in the present. The inclination to treat discourses on colonialism, war, and genocide as discrete is refused by such a gesture toward sound, and their differences are laid bare for analysis. Indeed, it is in the resonant movement of concepts such as genocide, war, and

\footnotetext{
${ }^{10}$ It is important to mark here that no Nazi was charged with the crime of genocide at Nuremberg, but that these persons were in fact charged with war crimes. Although the word genocide was used (once) during the Nuremberg proceedings, it only acquired the status of criminal offense in 1948 .
} 
colonialism that we might hear the unsettling of their groundedness, in either Europe or its Other. In the most salient ways genocide, war, and colonialism are marked by their intent: to destroy, to resolve, and, finally, to civilize. These intentions are further emboldened by a desire to improve the ways in which their intent becomes method.

In order to undo history's fetishism of the document, to underscore the present as the site in which memory unfolds, and to remind us of the precarity of time and temporality as concepts that belong to both, aurality might offer us a means through which to articulate that which we posit may be thought as the eddying entanglements of Africa and the global mnemoscape. This churning of the global mnemoscape can be read as an effect of an encounter with the discourses of war, colonialism, and genocide when engaged not only from the vantage point of Africa, but through thinking Africa.

It should be said that aurality, or rather a discourse of sound, is not new to studies of the past, but it certainly complicates any universal relation to the past. In fact, it can be argued, and has been, that it is in studies of the past that sound has shown its propensity for excess as well as its inherent critique of a discourse of recovery. ${ }^{11}$ Elsewhere, sound and Africa both as place and idea are intertwined in a pursuit of the past. The relationship between aurality and colonialism is at the core of the birth and development of another discipline-ethnomusicology-whose founder Erich Moritz von Hornbostel took it upon himself to record on a phonograph the infamous "Hottentot Venus" Sarah Baartman in order to not only articulate the differences between Western and non-Western physiognomy, but to address what he called the need to "uncover the darkest and most distant past [and] to peel off the timeless and elemental from the fullness of the present."12

${ }^{11}$ Sound as it has been deployed in the discipline of history has been characterized by a historicist impulse, resulting in a teleology that merely seeks to augment narrative with new aural actors. What is important to note here is the idea that sound is not merely hearing, and that soundscape-a sonic deployment of technologies of mapping-is a critical concept. Daniel Bender, Duane J. Corpis and Daniel J. Walkowitz, "Editor's Introduction: Sound Politics: Critically Listening to the Past," Radical History Review 121 (2015): 1-7 (here 3).

${ }^{12}$ The precursor to what becomes ethnomusicology is comparative musicology, and is a discipline not only concerned with music, but how music might grant us insight into the temporal dimensions of culture proper. Eric Ames, "The Sound of Evolution," Modernism/ Modernity 10 no. 2 (2003): 297-325 (here 298). 
Hearing is ironically in many ways the mode through which the law attempts to address and, in rare exceptions, redress offenses against it, which in our discussion here is violence as we call terror and apartheid. In response to these genres of violence Ethiopia and South Africa staged different iterations of "the hearing" in which the former held what is referred to as the Red Terror Trials and the latter held the famous Truth and Reconciliation Commission. Both the Ethiopian Red Terror Trials and the Truth and Reconciliation Commission of South Africa were imagined as "the mode" through which political transition occurs "peacefully," requiring listening and hearing from and to both victims and perpetrators. ${ }^{13}$ It is in this sense that these iterations of the legal hearing required a willingness to be activated-to allow the past into the present without fixing it there, so as to listen and to respond to what is being heard with justice in mind. Said differently, to listen here is to endow the law with the quality of activism. It is in this sense that the listening that the legal hearing enables is a potential for a coming to terms with mnemonic legacies of violence.

Hearing, however, also implies mishearing, which is why it must be paired with listening. The term solidarity has at its core an implicit kernel that hints at listening in its etymological trace of communion, and what is required if we are to achieve a mnemoscape entangled in solidarity is a thinking through and from Africa that would produce a democratization of memory discourses. Africa has been lodged as one of the spatial and conceptual others of the West through the discourses of the modern episteme and its effects, not the least of which can be located in area studies and anthropology. Consider, for example, the contemporary trajectory of migrancy that posits the West (and those locales who are marked as its

\footnotetext{
${ }^{13}$ In law trials are usually distinguished from hearings, in the sense that the former is usually a drawn-out procedure in which a definitive and final decision is made after arguments are presented by both parties while the latter is faster in part because its object is to determine a temporary resolution to a matter. However, in the Ethiopian case, the decisions assumed final at Red Terror trials proved temporary in the sense that death penalties were converted to life sentences. Finally, in 2011, 23 members of the Derg serving these life sentences received official pardons by the state. See Yonas Abiye, "Ethiopia Pardons 23 Top Derg Officials," Ezega News, June 1, 2011, https://www.ezega.com/News/NewsDetails?NewsID=2919. Debate around the matter of amnesty and pardon had, however, been ongoing since the inception of the retributive mechanism of transitional justice in Ethiopia's inception, see Kjetil Tronvoll, C. Schaefer and Girmachew Alemu Aneme, eds., The Ethiopian red terror trials: Transitional justice challenged (New York: Boydell \& Brewer, 2009); Girmachew Alemu Aneme, 'Apology and Trials: The Case of the Red Terror Trials in Ethiopia,' African Human Rights Law Journal 6 (2006): 64-84.
} 
proxies) as always a destination: that to which is aspired spatially but also (as a consequence of the teachings of modernity) conceptually. The Rest (most of Africa, Asia, South America, etc.) are marked conversely as points of departure: that from which, according to the same epistemic logic, that same trajectory is to spatially and conceptually progress. This is how, through the schizogenic use of time, the discourse of anthropology denies the coevalness of ethnographic fieldwork and produces its object. ${ }^{14}$ It is in this sense and through the schizogenic use of time as method that various expressions of the mnemonic discourses of genocide, colonialism, and war have produced their object as knots of memory - both temporally bound and fixed. Said differently, the knot here acts as an anchor, holding in place what remains "there and then"-backwards, primitive, uncivilized-and separating it from the "here and now"-Western, modern/eurocentric, progressive. In "knotting" the Rest and Other of the West with catastrophe, the mnemonic discourses of genocide, war, and colonialism collapse time and space, to produce non-Western nations as perpetually "cold" societies, to borrow from Claude Lévi-Strauss, from whom Jan Assmann develops his theory of "cold" and "hot" memory. In Cultural Memory and Early Civilization: Writing, Remembrance, and Political Imagination, Assmann writes that "cold" and "hot" are two poles on the spectrum from primitive to civilized respectively, explaining also that "cold societies do not live by forgetting what hot societies remember-they simply live with a different kind of memory, and in order to do that, they must block out history." From this he posits that cold memories are the nodes of history that mark time, freeze it in place in order for it to be measured. Conversely, hot memory "not only measures out the past, as an instrument of chronological orientation and control, but it also uses past references to create a self-image and to provide support for hopes and for intentions." ${ }^{15}$ Hot memory, and indeed hot societies, in this sense use their cold counterparts for creating a self-image-or myth-of superiority and progression, of having developed from where their cold counterparts remain frozen. The deconstruction of this perception of Africa, an example of the democratization to which we referred earlier, requires an understanding of Africa as

\footnotetext{
${ }^{14}$ See Johannes Fabian, Time and the Other. How Anthropology Makes its Object (New York: Columbia University Press, 1983).

${ }^{15}$ Jan Assmann, Cultural Memory and Early Civilization: Writing, Remembrance, and Political Imagination (Cambridge: Cambridge University Press, 2011), 52, 62; cf Claude Lévi-Strauss, The Savage Mind (Chicago: University of Chicago Press, 1966).
} 
a concept and indeed articulating modes of thinking about the world that are non-Eurocentric. What the example of Ethiopia makes clear, furthermore, is that this requires grappling with Africa's unsettling of globally accepted definitions of genocide and colonialism - and in markedly different ways than elsewhere in the world.

Sound, more recently, has become a subject of the south, and is being called upon to do the work of solidarity. Unsurprisingly, it has followed the discursive contours laid out above, as a recent edited collection titled Remapping Sound Studies argues in its pursuit of a "Southern Sound Studies." When "south" is defined in the volume, it is not so much a description as it is a genealogy of the term as a rather stable category, with subtle unreferenced nods to both a Marxist revisionist historiography in South Africa (colonialism of a "special type") as well as terms such as "structural adjustment," and institutions such as the World Bank and the International Monetary Fund named. Where it begins with an account of the Enlightenment and Jean-Jacques Rousseau's conflation of sound and south, and the multiple associations with writing, speech, and communication that the audiovisual litany marked as ideological, the volume unfortunately returns to the territorialization it began with: the North's other. ${ }^{16}$ Once again, Africa is reduced to a site that history happens to- a context.

We are also reminded in rather plain terms, through the idea that the sonic event that is acousmatic is one that betrays its source, that the certainty of the relationship between the source of a sound, its cause, and its effect as sonic emission is not one that translates directly into the listener's experience. ${ }^{17}$ In other words, we cannot merely hear if we are to hear properly. We must, and with a political and philosophical urgency, listen. Listening is about posture/-ing and perspective, a gesture that posits that it is about the movement of the articulated into the visual. It is about a gaze that is not the gaze. We constitute listening here as precisely this work: as activism, as engagement, attentiveness, and action in the moment of turning when we hear the call for a democratization of the global

\footnotetext{
${ }^{16}$ The audiovisual litany is a term coined by Jonathan Sterne and refers to the various differences and dichotomies that surround the senses of sight and hearing. See Jonathan Sterne, The Audible Past: Cultural Origins of Sound Reproduction (Durham NC: Duke University Press, 2003), 15. Gavin Steingo and Jim Sykes. "Introduction: Remapping Sound Studies in the Global South," in Remapping Sound Studies (Durham NC: Duke University Press, 2019), 1-36.

${ }^{17}$ Brian Kane, Sound Unseen: Acousmatic Sound in Theory and Practice (Oxford: Oxford University Press, 2014), 7.
} 
mnemoscape. It is in the act of hearing and listening for and to Africa in a non-reductive sense that we may be able to engage Africa as a productive site from which to think, a site of activation and activism. It is therefore in this sense that we approach Ethiopia and South Africa not as sites of memory, but as mnemonic structures in and of themselves. They do not constitute an alternative to a global mnemoscape nor do they set the stage for a memory studies that would locate itself in Africa or in the global south. Rather, through their disobedience to historicism and to a memory studies that would favor shared remembering as a universal mode of mnemonic discourse, they constitute sites of countercurrents and counterflows.

\section{South Africa: Total War and the Time of War}

How might we remember a time of war that is not wartime? How might we listen to the sounds of war misrecognized? The idea of the state of emergency and what is called total war as it unfolds in the context of a settler colonialism that would script the world demands that we consider the formulation colonialism as violence alongside the notion that imperialism is war. ${ }^{18}$ What is called the military industrial complex of the South African apartheid state produced the notion of "total war" in relation to the political atmosphere of the Cold War, and this reveals an insecurity around the colonial state, imperial war, and the work of memory. Let us pause for a moment and consider the context of two particular terms that animated both the legal and administrative forces that characterized the various states of emergency in the 1980s in South Africa: total war and militarization. It is through the consideration of these terms as they oscillate in both the historiography and popular memory that we begin to see how temporality itself becomes a marker of insecurity. War, colonialism, and apartheid cease to be discrete objects, periods, or events if we attend to the ways in which these terms move.

By 1976, various events including the Soweto Uprising and the death of anti-apartheid activist Steve Biko in detention in 1977 in particular shifted the political landscape in South Africa and its two key actors, the state and resistance movements, leading to a United Nations arms embargo on South Africa. The discourses of the Cold War and the longstanding

\footnotetext{
${ }^{18}$ See, for example, the idea of global apartheid. See also Jacques Derrida and Peggy Kamuf, “Racism's Last Word," Critical Inquiry 12, no. 1 (October 1985): 290-99.
} 
conflation between communism and African nationalism (the red danger and the black danger) in the mind of the apartheid state drove a new administration under P.W. Botha to declare a new state policy in 1979: "total onslaught, total strategy." 19 In July of 1979, Botha would make the infamous "adapt or die" speech, in which he argued for significant reform of the apartheid system if the state in its current form were to survive the current domestic and international situation. Throughout this period, there was a debate both inside and outside the halls of power around whether South Africa was indeed at war. At times, the state would argue that it was facing a revolutionary onslaught that required the strategic intervention of the defense forces, and at other times it would state very plainly that the current situation of conflict in the country "involved so many different fronts, unknown to the South African experience, that it has gained the telling but horrifying name of total war." This was captured perhaps in the most telling manner through two specific instances in 1988. The first, which occurred during a treason trial, was a moment where the South African Police noted that the African National Congress could not be thought to be at war with the South African Government and that rather it should be seen in terms of the state facing a "revolutionary onslaught." This argument, according to Jacklyn Cock, was put forward simply to prevent ANC members claiming a prisoner of war status, a status which under the Geneva Protocols of 1977 is granted to those engaged in wars with colonial powers. The second is an instance where in order to circumvent the institution of an order brought by the End Conscription Campaign to restrain the South African Defense Force from harassment, the state argued that because the South African Defense Force (SADF) was on a "war footing," such an intervention was outside of the jurisdiction of the Supreme Court. ${ }^{20}$

${ }^{19}$ The idea of the red danger, or die rooi gevaar, came to refer to the threat of communism in the language of the apartheid state and its tactical positioning in relation to liberation movements. It also became synonymous with the idea of the black danger, or die swart gevaar, a racialized fear of black settlement in white urban areas dating back to the 1930s before the adoption of apartheid policy in 1948. James Selfe "The Total Onslaught and the Total Strategy: Adaptations to the Security Intelligence Decision-Making Structures under P W Botha's Administration" (Unpublished MA thesis, University of Cape Town, 1987), 1-4. For more on the state security apparatus, see James Selfe, "South Africa's National Management System," in War and Society: The Militarisation of South Africa, eds. Jaclyn Cock and Laurie Nathan (New York: St. Martin's Press, 1989), 149-58.

${ }^{20}$ Jacklyn Cock, "Introduction," in War and Society: The Militarisation of South Africa, eds. Jaclyn Cock and Laurie Nathan (New York: St. Martin's Press, 1989), 1-13 (here 1). 
What this series of events did was place the military apparatus in South Africa in a precarious position both inside and outside of politics. Here, militarization was an ideological formation, with its power and influence operating as a social institution with its own networks of cultural memory. What it meant to be at war and to be prepared for war would come to define what the soldier was and what the civilian was, including their own histories of becoming as national identities. It would also, ironically, suture the enemy into the very fabric of that becoming. It was imperialism. It was total war.

It was in this guise of total war that apartheid as a bureaucratic structure would stage its last stand as a series of states of emergency, formalized periods of militarization, and the suspension of human rights in favor of humanitarian principles. More important, however, is that the idea of total war as it unfolds in South Africa (and considering the various military operations of the apartheid state further afield in Southern Africa) reveals to us a temporality around state violence and a relationship to imperialism that must be considered if we are to embark upon the work of entangling memory to achieve a more democratic mnemoscape. To understand how we can constitute a global mnemoscape, we must first look at how the skirmishes of encounter-the small wars of empire that came to constitute the pre-history of South Africa's "total war"-are remembered.

The central feature of the discourse of total war is the inability to name war as anything but one homogenous and discrete temporality, a temporality that cannot but reproduce a teleology that ends in the nation-state, and one that produces a soldier with excess. The Battle of Salt River that would be deemed the inaugural military altercation in South Africa in 1510 , is one example which, when attended to, shows up the tension at the heart of this formation. That tension appears not in the historical periodization or narrative structures that govern its retelling in the historiography, but rather in its mnemonic movement: its deployment into cultural memory as a silent marker of what it means to be a soldier in South Africa, and what it means to be a South African soldier. The mnemonic structure that emerges here is a set of ideas and practices surrounding what is called veldcraft. As the story goes, Portuguese Viceroy of India Dom Franscisco de Almeida and his men engage an altercation with the indigenous Khoi people of the Cape that results in the death of de Almeida and his crew on the banks of the Salt River (near present-day Cape Town, South Africa) in 1510. The skirmish, which is characterized by a specific "tactic" used by the Khoi-a "phalanx of oxen controlled by whistles and shouts"-is 
recruited to produce a long historical view of the soldier who must defend the nation, or the warring subject who must protect the nation to come. The altercation, which dissuaded the Portuguese from pursuing any further contact in Southern Africa for another 80 years, would come to mark the onset of a long history of practice of war that cut across the political positioning of competing military forces in the history of conquest and colonialism and resulted in a military practice that draws its key aspects from both colonized and colonizer. This military practice is called veldcraft, and according to military historians it is a tactic that underwrites the Dutch Staatse Leger (State Army) doctrine, the commando system of the Boers during the South African War in the early 1900s, the regimental system of the Zulu army in the nineteenth century, Basotho horsemen and the modern South African soldier of the 1980s-all subsumed into a single narrative of a national and geopolitically specific military strategy. ${ }^{21}$ The South African soldier is born out of veldcraft, and veldcraft is the inaugural mnemonic discourse that becomes practice in the service of total war.

What we might call the mnemonic fragment that is the Khoi leading their livestock in military formation with non-vocal vocalizations is transformed into tactic: its recollection, remembering, and calling into service directly subsumed into a discourse of practice, and critically, a practice, technique, and indeed apparatus that operates within the logic of defense and is by definition warring. It now cannot be rendered as anything other than this, and its recollection is bound to the state and to a particular temporality associated with war. It is a practice however, that not only produces a long history of warring in Southern Africa but also produces a mnemonic discourse around land, voice, war, and the indigenous. It is in the land that cannot speak and must be spoken for (read, read) that the Khoi are subsequently buried through the transformation of this memory into practice. ${ }^{22}$ It is through what is called veldcraft - the very name

${ }^{21}$ Willem P. Steenkamp, "The Shaping of the South African Soldier, 1510-2008," Journal for Contemporary History 34, no. 1 (2009): 207-22.

${ }^{22}$ It is also ironic that the Battle of Salt River is also called the first war of resistance against European aggressors, with former state president Thabo Mbeki invoking it in relation to his project of African Renaissance which argued for an intellectual renewal of Africa. It is also in this sense that the category of veldcraft should be thought alongside ethnographic histories of indigeneity in South Africa, where the relationship between the Khoi and the San (often referred to by the derogatory term 'Bushman') to land and nature is one marked by a conflation which is at the heart of the exclamation that the San are historically the closest to 
replaces the Anglicized bush with its more located Afrikaans term, veld, implying control and dominion-that the memory of the Khoi and their aurality would travel in time and through time, timelessly. ${ }^{23}$ When this mnemonic fragment becomes a tactic, it transforms into a vehicle- a technique-for remembering that is practiced in relation to power. We might observe the ways in which historiography facilitates this process as the production of tradition; the Khoi disappear into their aural markers (the whistles and shouts) and indigenous tradition remains but only as warring. The small war of 1510 is subsumed into total war, unwittingly revealing to us the discursive traces that make up an untenable concept of war and a wartime that only history can hold.

The soldier must be the recipient of a nascent wartime, not only to carry the temporalities of the past into uncertain futures but also to embody its rhythm that is both kairos and chronos, both in time and on time. It comes to mark his or her body in the wake of unspeakable violence. It comes as no surprise that the transition-which was in itself a movement from a state of emergency to an emergent state-was haunted by how South Africa might resolve a crisis of military institution. What was a postapartheid army to look like and act, given the horrific reputation the South African army had crafted for itself both in Africa and abroad? How would it resolve the various categories of defender of the nation, categories that included insurgent, commandant, terrorist, and conscript? ${ }^{24}$

The latter is not a question that will be addressed here, but it points to another matter, that is, the ways in which the tension at the heart of the inability to name war in South Africa may have a longer if not more encompassing genesis. Adam Sitze reminds us that imperial war-often described as the "small wars" of empire and taking place in what is regarded in the metropole as peacetime-is critical to the very theoretical base of

humanity's earliest ancestors. See David Johnson, Imagining the Cape Colony: History, Literature, and the South African Nation (Cape Town: University of Cape Town Press, 2012), 10-34.

${ }^{23} \mathrm{On}$ the ways in which the idea of tribe and native congeal in the production of the Afrikaner and its stakes for considering identity politics, race, and nationalism in South Africa, see Suren Pillay, "Where do you belong? Natives, foreigners and apartheid South Africa," African Identities 2, no. 2 (2004): 215-32.

${ }^{24}$ See Lephophotho Mashike, “'Blacks Can Win Everything, but the Army': The 'Transformation' of the South African Military between 1994 and 2004," Journal of Southern African Studies 33, no. 3 (2007): 601-18. 
empire as such. ${ }^{25}$ Mary Dudziak emphasizes the relation between wartime and peacetime, and how this has effects not only in the realm of law, but also on the discipline of history by considering the ways in which the onset of war marks not an event but an era that is temporary. ${ }^{26}$ What Dudziak alerts us to is the ways in which war is textured by an eventness that exceeds event. It is no surprise therefore that war is a barometric structure for empire itself, as Sitze tells us; it not only provides the terms upon which to determine the overall health and status of an imperial endeavor, but also affects how empire thinks about justice, morality, and its ultimate goal. It is that which gives imperialism its meaning, its ultimate philosophical force. Interestingly, considering the ways in which apartheid has been theorized as an economic system designed to exploit the labor of black bodies and furthermore as an articulation of a neoliberal ideal, Sitze argues that there is a fundamental contradiction at the heart of imperial war that the imperial administrator must manage: a dialectic between war and capital. In essence, imperial war must save imperialism from its own suicidal drive. ${ }^{27}$ It serves to defer its own death. What can a time of war that is not wartime tell us about imperial time? How is the work of rememberingthat is, suturing the relationship between the past and present-to take place in the wake of such a complicated relationship between the historicity of the present and a historicism of the past?

It was, after all, the fall of the Berlin Wall that not only ushered in the end of apartheid as a legal system but also a concept of historicity that would seek to reify the past as unchanging, unshifting, and static. It would also be the period that would give birth to memory studies proper. This historicity, which bears the battle scars of a modernist paradigm, cannot think the way memory does: in the present and with a drive toward reconstitution. The rise of a temporality - a mnemonic structure in and of itself-interested in how the past (re)-presents the present is one that uncovers for us the ways in which war and its scripts become visible. What we are calling the military industrial complex of the apartheid state-that network of state, violence, and world-historical force-is in fact total war: imperialism proper.

${ }^{25}$ Adam Sitze, “The Imperial Critique of Imperial War," Filosofia Politica 25, no. 2 (August 2011): 315-34 (here 316).

${ }^{26}$ Mary L. Dudziak, War-Time: An Idea, Its History, Its Consequences (New York: Oxford University Press, 2012).

${ }^{27}$ Sitze, “The Imperial Critique," 333. 
This is an argument we can only make now, in this present, given the ways in which the memory of wartime in South Africa is unresolved and contested. It is through wartime that the nation can be and is imagined in the present; an imagining that collapses the various divisions between colonial conquest, states of emergency, and global war. We can explore this most prominently in the example of the sunken troopship the $S S$ Mendi, whose memory has been invoked multiple times in contemporary South African politics to imagine a long unbroken history of the quintessential South African soldier. ${ }^{28}$ In particular, the SS Mendi becomes metonymic for the black soldier, or the infantrymen of the South African Native Labour Contingent: a battalion of black soldiers sent as labor to the frontlines in World War I, to not only face a war unarmed but to be the subjects of a testing ground for segregation. ${ }^{29}$ The iconic moment of the death drill-when a certain Reverend Isaac Dyobha led soldiers on the sinking ship in a dance of death-is central to the retelling of the narrative of the sinking of the SS Mendi. The death drill, as it is often recalled, is one that calls forth a unified, multiracial and multicultural national subject, and interweaves it into the figure of the soldier who must defend the nation to come. Dyobha led the men with the following invocation:

Be quiet and calm, my countrymen, for what is taking place is exactly what you came to do. You are going to die ... but that is what you came to do... Brothers, we are drilling the death drill. I, a Xhosa, say you are my brothers. Swazis, Pondos, Basutos, we die like brothers. We are the sons of Africa. Raise your war cries, brothers, for though they made us leave our assegais in the kraal, our voices are left with our bodies.

In an act of re-membering, the death drill has found itself at the center of a novel titled Dancing the Death Drill by author Fred Khumalo dramatizing a black recruit of mixed racial heritage surviving the tragic sinking. The narrative hinges on its opening salvo: an unprecedented violent act in a Parisian restaurant is figured as an outburst of latent anger harbored from a betrayal as the SS Mendi sank. The betrayal is explored through a

${ }^{28}$ John Gribble and Graham Scott, We Die Like Brothers: The Sinking of the SS Mendi (Swindon: Historic England, 2017); Albert Grundlingh, "Mutating Memories and the Making of a Myth: Remembering the SS Mendi Disaster, 1917-2007," South African Historical Journal 63, no. 1 (2011): 20-37 (here 31).

${ }^{29}$ See Brian P. Willan, "The South African Native Labour Contingent, 1916-1918," The Journal of African History 19, no. 1 (1978): 61-78. 
reimagining of the complicity of the captain of the Darro, who refused to help the SS Mendi because of its black crew. In an almost foreboding sense, the tragedy is inserted into a network of collective memory closely tied to the idea of South Africanness born out of the transformation from traumatic memory into narrative memory that was the discursivity of the Truth and Reconciliation Commission. ${ }^{30}$ The SS Mendi and the moment that comes to be associated with it - the dancing of the death drill as the ship sank-is immortalized in Khumalo's novel Fred Khumalo not only through its title, but in the ways in which the death drill becomes the core temporal narrative device through which the novel simultaneously attempts to work through the tragic circumstances of the sinking of the SS Mendi and make sense of its return as a temporal object in the postapartheid present. In the final scene of the novel, the protagonist deploys the death drill- that sonically charged mnemonic device-as the quintessential structure of subject formation:

"I am dancing my death drill. No one can take it away from me. This death drill is my truth. They made me leave my spear, my shield, back home those many years ago. So I am going to fight with my words, turn my words into bullets. This dance is my history, my heritage, my story that they tried to suppress. This is my death drill, my dance of death, my dance of truth.” Like the men on the Mendi, he danced, the rhythmic slamming of feet gaining momentum with each movement. Slam-slam! Slam-slam! ${ }^{31}$

A specific articulation of wartime has provided the script through which the warring subject forces the past into the present, in ways that uncannily replicate the scripts of a historicity that would seek a teleological resolution. This resolution is made on the warring subject. What we are construing as war is memory masquerading as history, a linear, homogenous and causal notion of time that cannot move freely.

\section{CONCLUSION}

What is being termed solidarity is a manner through which to account for a flattening of the mnemonic landscape-intended or otherwise. This flattening has at its core a desire to constitute a world that remembers

\footnotetext{
${ }^{30} \mathrm{Cf}$ Paul Gilroy, "Lecture I. Suffering and infrahumanity lecture II. Humanities and a new humanism," Tanner Lectures (2014): 69.

${ }^{31}$ Fred Khumalo, Dancing the Death Drill (Cape Town: Umuzi, 2017), 335.
} 
collectively, that puts its past together in moves that must be named solidarity. To entangle memory therefore is to constitute a temporality that might transcend the notion of progress that world history has given us as the ideal script. What the examples of Ethiopia and South Africa reveal is that attention must be directed toward the notion of the apparatus: juridical, imperial, mnemonic, disciplinary, technological, or otherwise. Thinking in terms of apparatus could be constitutive not only of how we might approach mnemonic solidarity as a call, but also how it is we might reckon with Africa in the moment of such a hailing. Indeed, what was made apparent in our examples was the question of technique: a working on the subject that cannot be neatly subsumed into what has been called the global mnemoscape. For example, Ethiopia proves critical if we are to think the mnemonic through its technicality; the Ethiopian Red Terror as an example of genocide sits precisely within that work of memory called forgetting. It is that expression of genocide, within a space never colonized, that genocide studies largely refuses to remember. What is at stake in the Ethiopian example of the eddying of genocide and terror-of the swirling, mixing, and churning of two distinct violations of international law-is the question of the lived, human experience of the atrocities that still-now sear of their everyday. The Ethiopian Red Terror is largely forgotten within the discourse of genocide; and yet remains always present in the memory of those who lived through and survived it. It is in relation to this that the desire for mnemonic solidarity and the democratization of the mnemonic discourses of genocide, colonialism, and war is a desire for abiding by the fluidity of memory. Said differently, it is a desire that gestures toward making the practice those discourses not knotting but eddying.

Similarly, it is the uncertainty of memory as it is deployed to do the work of history that comes to churn the mnemonic in the case of South Africa. If temporality comes to mark the history of war in South Africa, it is because the soldier is a subject that travels across time and complicates how we configure war and its conceptual and discursive histories on the continent. The soldier is the subject that neither history nor memory can hold alone and is therefore a troubling prospect for a mnemoscape which must exceed the nation in its shape. It is precisely because total war and militarization cannot but must sit alongside each other that we are forced to recognize that perhaps what is considered universal must instead be thought as undemocratic. What mnemonic solidarity might then mean is an attentiveness to movement rather than situatedness. We are compelled 
to read a global mnemoscape on the grounds of churning rather than entanglement. It is in the techniques through which memory is recruited to make sense of the disjointed time of war that we notice the intertwining of the work of history and memory. The whistle and shout and the death drill are both sonic mnemonic apparatuses that are both memory and transformed into memory and set to work to make sense of how the soldier and its excessive subjectivity can be held in a larger national narrative.

The noun memory is, as we know, intrinsically entangled with the past, but when put to work, indeed sounded out a verb, it defies its temporal limits and when recalled it is once again present. Memory in the singular is a condensation of fragmented remnants of lives, histories, and narratives-individual and collective, trans-generationally and locally textured. It is this capacity of the human that has germinated a field of study, and it is beyond the scope of this chapter to debate what precisely the work of memory studies is. Rather this chapter is concerned with how it is that the discourses of genocide, war, and colonialism contour the mnemoscape in ways that resist the neatness of rendering the objects of any of these discourses discrete. It is a gesture toward working through the desire for the deterritorialization of the mnemoscape, as simultaneously contextually sanded by the local and global, but not universal. To put it another way, this chapter looks toward a democratization of the global mnemoscape that is not inherently liberal. To do so we turn to Africa as not a cartographic and geological location but as a concept and methodology.

Open Access This chapter is licensed under the terms of the Creative Commons Attribution 4.0 International License (http://creativecommons.org/licenses/ by $/ 4.0 /$ ), which permits use, sharing, adaptation, distribution and reproduction in any medium or format, as long as you give appropriate credit to the original author(s) and the source, provide a link to the Creative Commons licence and indicate if changes were made.

The images or other third party material in this chapter are included in the chapter's Creative Commons licence, unless indicated otherwise in a credit line to the material. If material is not included in the chapter's Creative Commons licence and your intended use is not permitted by statutory regulation or exceeds the permitted use, you will need to obtain permission directly from the copyright holder.

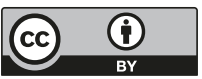

